\title{
Imprensa e Mundos do Trabalho: a singularidade da Imprensa Operária no Amazonas*
}

Luciano Everton Costa Teles

ReSUmo: O presente artigo procura elucidar a relação entre História e imprensa, enfatizando a imprensa operária como objeto-fonte de estudos, revelando as potencialidades desta relação para a produção do conhecimento histórico. Focaliza também algumas questões presentes em suas páginas, destacando uma configuração específica e assuntos relacionados e direcionados ao universo operário.

Palavras-chaves: História, Imprensa Operária, Mundos do Trabalho.

ABSTRACT: this article seeks to elucidate the relationship between history and press, emphasizing the press Riveter as source object of study, revealing the potential of this relationship for the production of historical knowledge. These questions also Focuses on their pages, highlighting a particular configuration and related subjects and directed to universe workman.

Keywords: history, Press Riveter, Worlds of work.

\section{HISTÓRIA E IMPRENSA}

A imprensa é tomada pela história em dois sentidos: como objeto de estudo ou como fonte para a pesquisa histórica. Portanto, para elucidar as dimensões desta relação é necessário considerar esses dois eixos.

A imprensa tomada como objeto de estudo nos remete, num primeiro momento, aos Institutos Históricos e Geográficos espalhados pelas regiões do país e aos intelectuais ligados a essas instituições, com destaque para Alfredo de Carvalho e Afonso de Freitas. Os trabalhos desenvolvidos por esses profissionais consistiam na realização de levantamentos

* Este artigo foi construído com base no primeiro capítulo de minha dissertação de mestrado, “A Vida Operária em Manaus: Imprensa e Mundos do Trabalho" (1920), defendida em outubro de 2008 no interior do Programa de Pós-graduação em História da Universidade Federal do Amazonas.

** Mestre em História Social pela Universidade Federal do Amazonas. Professor e Coordenador do curso de Licenciatura Plena em História do Centro Universitário Nilton Lins e professor substituto da UFAM. E-mail: lucianoeverton777@hotmail.com. 
de jornais e abordagens descritivas sobre eles. Deste modo, a imprensa era vista por uma perspectiva descritiva, factual e cronológica.

Sob essa perspectiva, Marialva Barbosa alegava que "escrever a história da imprensa não é, certamente, alinhar fatos e datas, nomes e mais nomes, nem destacar os personagens que se tornaram singulares na construção engendrada no passado para o futuro" ${ }^{1}$.

Com efeito, a tentativa de construção de uma história da imprensa no Brasil não se restringiu a este primeiro momento. Em 1966 surgiu a História da Imprensa no Brasil ${ }^{2}$, obra de vulto que reflete sobre a dinâmica e evolução dos órgãos de Imprensa e analisa suas características em diversas conjunturas. Ancorado em um modelo marxista que atrelava a dimensão cultural ao nível da infraestrutura - aquela era reflexo desta -, Sodré via a imprensa como um "aparelho ideológico do estado". Esta dimensão pode ser percebida logo no início do livro, quando afirma: "a história da imprensa é a própria história do desenvolvimento da sociedade capitalista" ${ }^{3}$.

Porém, esta não é a única obra que procurava construir, por um outro viés, uma história da imprensa no Brasil. Precedendo a obra de Sodré, Juarez Bahia ${ }^{4}$ procurou discutir não só um sentido geral na história da imprensa brasileira, mas também inquirir essa historicidade em articulação com os processos de incorporação de novas tecnologias e linguagens. Além de Bahia, Carlos Rizzini ${ }^{5}$ e Hélio Viana ${ }^{6}$ também desenvolveram estudos sobre os órgãos de imprensa em perspectiva global.

Considerando as obras que buscavam analisar globalmente a história da imprensa do Brasil, Geraldo Pinheiro assim se posicionou:

não obstante a grande contribuição que estes trabalhos trouxeram ao debate contemporâneo, eles carregam limitações de suas época. Assim pois, Carlos Rizzini, Hélio Viana e Juarez Bahia estão fortemente marcados por perspectivas positivistas, enquanto Nelson Werneck Sodré, com a ortodoxia que lhe é peculiar...

1 BARBOSA, Marialva. Como escrever uma história da imprensa? Texto apresentado no II Encontro Nacional da Rede Alfredo de Carvalho, Florianópolis de 15 a 17 de abril de 2004.

2 SODRÉ, Nelson Werneck. História da Imprensa no Brasil. 4ae ed. Rio de Janeiro: Mauad, 1999.

${ }^{3}$ Idem, p. 1.

${ }^{4}$ BAHIA, Juarez. Jornal, História e Técnica: história da imprensa brasileira. 4ae ed. São Paulo: Ática, 1990.

${ }^{5}$ RIZZINI, Carlos. O Livro, o Jornal e a Tipografia no Brasil. São Paulo: Imprensa Oficial, 1988.

${ }^{6}$ VIANA, Hélio. Contribuição à história da imprensa brasileira (1812-1869). Rio de Janeiro, Ministério da Educação/INL.

${ }^{7}$ PINHEIRO, Geraldo Sá Peixoto. "Imprensa e Modernidade: relato de pesquisa em curso". Amazônia em Cadernos, n²/3, Manaus, Universidade do Amazonas, 1993/4, p.198. O autor estabelece também a divisão cronológica realizada por Sodré e Bahia. Enquanto aquele optou por uma divisão que acompanha a periodização tradicional da historiografia brasileira (Imprensa Colonial, Imprensa da Independência, Imprensa do Brasil Império e da República, subdividindo esta em dois capítulos: a grande Imprensa e a crise da Imprensa brasileira), este a divide em três grandes períodos, chamando-os de "Etapa Inicial" (1808 1880), “Fase de Consolidação" (1880 - 1930) e “Fase Moderna” (1930 - 1960). Idem, p. 197-198. 
Cabe mencionar que os estudos menores e mais regionalizados não ficaram de fora. Nesta linha, a obra de Ignotus $^{8}$, que abordou a imprensa no Maranhão entre 1820 e 1880, e Luiz do Nascimento ${ }^{9}$, que focalizou a imprensa em Pernambuco, são exemplares.

Desta forma, a partir da segunda metade do século XIX até meados da década de 70 do século $\mathrm{XX}$, os estudos que tomaram a imprensa como objeto de estudo, ora em plano global ora em plano regional, caminharam em duas vertentes. Na primeira, a imprensa era encarada de forma descritiva, factual, cronológica e preocupada em fazer levantamentos de documentação sobre jornais (catálogos e listagens). Nesta perspectiva há um baixo teor explicativo. Na segunda, o jornal era visto como "aparelho ideológico do estado", o que acaba por gerar um empobrecimento analítico resultante do determinismo econômico.

Nas décadas subsequentes, a noção de imprensa enquanto "prática social que compunha o tecido social urbano" se difundiu e contribuiu para a emergência de trabalhos relevantes, com destaque para o trabalho de Heloisa de Farias $\mathrm{Cruz}^{10}$, que buscou refletir as relações entre cultura letrada, periodismo e vida urbana no processo inicial de formação da metrópole paulistana.

No Amazonas o campo da história da imprensa ainda está por ser desbravado, o que não significa dizer que não existam produções referentes ao tema. Um pioneiro estudo sobre a história da imprensa no Amazonas foi realizado em 1908 por um grupo de intelectuais locais, com destaque para João Batista de Faria e Souza e Alcides Bahia ${ }^{11}$. Tal produção foi formulada no bojo das comemorações do primeiro centenário da história da imprensa no Brasil. Embora partindo de uma modesta visão de conjunto da imprensa no Amazonas, esse estudo foi importante por ter chamado a atenção para a riqueza daquela produção jornalística, a partir da listagem de mais de três centenas de jornais que circularam na região, desde a implantação da Província, em 1851, até 1908, ano de sua publicação.

$\mathrm{Na}$ mesma linha de preocupação, foi elaborado o Catálogo dos Cem Anos de Imprensa no Amazonas ${ }^{12}$, produzido por um conjunto de historiadores da Universidade Federal do Amazonas. Nesta obra buscou-se ampliar o quadro dos jornais publicados no Amazonas, com rápida apresentação que não só reavaliava a dinâmica do periodismo local, como também reafirmava sua importância como relevante fonte para a renovação historiográfica.

${ }^{8}$ IGNOTUS, A Imprensa no Maranhão, 1820-1880: sessenta anos de jornalismo. Rio de Janeiro: Editores Faro \& Lino, 1883.

${ }^{9}$ NASCIMENTO, Luiz do. História da Imprensa de Pernambuco (1821-1954). Recife: Editora Universitária de Recife, 1972.

${ }^{10}$ CRUZ, Heloisa de Faria. São Paulo em papel e tinta: periodismo e vida urbana (1890-1915). São Paulo: EDUC, 2000.

${ }^{11}$ FARIA E SOUZA, João Baptista, SOUZA, Monteiro de e BAHIA, Alcides. A Imprensa no Amazonas, 1851-1908. Manaus: Tipografia da Imprensa Oficial, 1908.

${ }^{12}$ FREIRE, José Ribamar Bessa (Coord.). Cem Anos de Imprensa no Amazonas (1851-1950) - catálogo de Jornais. Manaus: Editora Calderaro, 1990. 
As obras acima referendadas são catálogos e listagens que embora contribuam enormemente como instrumentos de pesquisa, "não trazem uma maior profundidade interpretativa acerca dos materiais alvo dessas publicações" ${ }^{13}$.

Não obstante, mais recentemente o periodismo amazonense foi alvo de adensado estudo analítico, em que se buscou não apenas asseverar a heterogeneidade de formatos, linhas editoriais e projetos político-sociais que embasaram a Imprensa Amazonense entre os anos de 1880 e 1930, como também discuti-la como peça-chave de expressão e avanço da cultura letrada no Estado. ${ }^{14}$

De igual forma, coube a Pinheiro a tentativa de mapear, descrever e analisar as "folhas operárias" que circularam no Amazonas, abrindo entre nós um campo já consagrado no interior das principais universidades e centros de pesquisa brasileiros.

A utilização da imprensa periódica como fonte para a pesquisa histórica brasileira ganhou terreno, ainda de forma tímida e lenta, na década de 1970, após a superação de antigas posturas que marcaram a prática historiográfica, notadamente as noções de "fonte suspeita" e "repertório da verdade". De início, os jornais eram vistos com desconfiança. Os diversos temas tratados e as inúmeras informações veiculadas, por não serem oficialescas na medida em que não eram documentos comprovadamente produzidos por agentes do governo -, eram relegados a um plano secundário. Entretanto, para aqueles que insistiam em utilizá-los era necessário redobrar a atenção, a fim de não comprometer, com o uso desses registros, a pretensa objetividade, tão ardorosamente desejada no interior da disciplina histórica.

Num extremo oposto, foi lentamente se constituindo a ideia de "fato verdade", que elegia o jornal como "templo dos fatos", enaltecendo a objetividade do fato jornalístico e esboçando uma tendência a utilizar a imprensa como relato fidedigno da realidade, fonte imparcial e neutra dos acontecimentos ${ }^{15}$.

É na década de 70 e início de 80 do século $X X$ que os jornais passaram a ser encarados de forma diferente. No processo de reavaliação do tratamento dispensado pelo historiador às fontes históricas, os jornais passaram a se apresentar como espaços de representação de inúmeros aspectos da realidade. A partir deste momento, a atenção se voltou para os elementos constitutivos da construção dos textos jornalísticos. Esta postura foi difundida e acabou influenciando os historiadores, que caminharam no sentido de romper com a postura que via os jornais como "fonte suspeita" ou, inversamente, como "repertório da verdade" e permitiu estabelecer questões que procuravam elucidar não o fato jornalístico em si, mas a construção deste fato. Atentou-se que na construção do fato jornalístico os elementos subjetivos e os interesses do jornal interferiam decisivamente. Desta forma, a tarefa preliminar de identificar os elementos construtores do fato se tornou

\footnotetext{
${ }^{13}$ PINHEIRO, Maria Luiza Ugarte. Folhas do Norte: letramento e periodismo no Amazonas, 1880-1920. Tese de doutorado em História. São Paulo: PUC, 2001, p. 58.

${ }^{14}$ PINHEIRO, Maria Luiza Ugarte. Folhas do Norte... Op. Cit.

${ }^{15}$ CAPELLATO, Maria Helena. Imprensa e História do Brasil. São Paulo: Contexto/Edusp, 1994.
} 
central na construção historiográfica, uma vez que possibilitava identificar e localizar o jornal socialmente e, assim, melhor compreender a logicidade de seus discursos e a emergência de projetos de intervenção social e política que, por vezes, eles buscavam encobrir.

Assim, a adoção de uma postura cautelosa e crítica no trato com a imprensa se tornou referência obrigatória para os pesquisadores. Zicman lembrava que para os que resolviam tomar a imprensa como objeto/fonte de estudo historiográfico era necessário atentar para o eixo norteador de sua ação - o campo político e ideológico. Esta questão trouxe consigo a necessidade de estabelecer os principais traços característicos dos órgãos de imprensa a serem investigados ${ }^{16}$. Era preciso indagar ainda sobre o modo como os jornais constituem formas de olhar e narrar os eventos e de fixar uma versão, entre outras possíveis. Era preciso identificar o "lugar social de onde cada jornal fala"17.

Esse processo foi importante, uma vez que deu à imprensa um lugar de destaque nos estudos históricos, tal como sustenta Maria Helena Capelato:

Manancial dos mais férteis para o conhecimento do passado, a imprensa possibilita ao historiador acompanhar o percurso dos homens através dos tempos. 0 periódico, antes considerado fonte suspeita e de pouca importância, já é reconhecido como material de pesquisa valioso para o estudo de uma época18.

Como fonte histórica, a imprensa configurou-se como um "manancial dos mais férteis" para a reconstrução e elucidação do passado. Por meio dela, tornou-se possível recuperar dimensões sociais importantes, notadamente as lutas, os ideais, os compromissos e os interesses de diversos setores que compõem a sociedade. A imprensa possibilitou um melhor conhecimento das sociedades quanto a suas condições de vida, manifestações culturais e políticas, dentre outros aspectos.

Desta forma, do ponto de vista de uma "História através da Imprensa", é possível identificar vários trabalhos bastante significativos, articulados à produção de uma História Operária no Brasil. Entre eles estão as obras de Maria Auxiliadora Guzzo Decca, Sidney Chalhoub, Francisco Foot Hardman, Ângela de Castro Gomes, dentre outros. ${ }^{19}$

Embora os chamados "anos de ouro" da história operária se encontrem justamente na década de 1980, no Amazonas, em que pese o esforço de um conjunto de historiadores no sentido de revisitar e renovar a produção histórica regional, ainda é preciso ampliar os

\footnotetext{
${ }^{16}$ ZICMAN, Renée Barata. Op. Cit., p. 91-92.

${ }^{17}$ VIEIRA, Maria do Pillar et al. A Pesquisa em História. São Paulo: Ática, 1989.

${ }^{18}$ CAPELATO, Maria Helena Rolim. Imprensa e História do Brasil. São Paulo: Contexto/Edusp, 1988, p. 13.

${ }^{19}$ DECCA, Maria Auxiliadora Guzzo. A Vida Fora das Fábricas: cotidiano operário em São Paulo, 1920-1934. Rio de Janeiro: Paz e Terra, 1997, CHALHOUB, Sidney. Trabalho, Lar e Botequim: o cotidiano dos trabalhadores no Rio de Janeiro da Belle Époque. São Paulo: Cia das Letras, 1991, HARDMAN, Francisco Foot. Nem Pátria, Nem Patrão! Vida operária e cultura anarquista no Brasil. São Paulo: Brasiliense, 1983 e CASTRO GOMES, Ângela de. A Invenção do Trabalhismo. São Paulo: Vértice, 1988.
} 
estudos. Os trabalhos de Ednéa Mascarenhas Dias ${ }^{20}$, Maria Luiza Ugarte Pinheiro ${ }^{21}$ e Francisca Deusa Sena da Costa ${ }^{22}$ contribuíram nesse processo.

A historiografia regional tradicional ocultou as condições de vida e trabalho das populações citadinas marginalizadas. Silenciou os ideais, as lutas e os projetos destes grupos, que atuaram de forma bastante efetiva no processo histórico amazonense. Felizmente este silêncio da historiografia tem sido minimizado por novas abordagens que surgiram, proporcionando novas interpretações do passado.

Nesta esteira, o presente artigo tem como objetivo discutir a imprensa operária enquanto objeto/fonte de estudos, destacando-a como significativa para a produção do conhecimento histórico. É propósito ainda deste artigo apresentar o jornal Vida Operária, que circulou na cidade de Manaus no ano de 1920 e recebeu apoio e sustentação de diversas associações operárias. Por meio dos seus 26 títulos publicados apresentou denúncias, dilemas e projetos políticos direcionados à classe operária, revelando a Imprensa como "prática social e momento da constituição/instituição dos modos de viver e pensar".

A importância da imprensa operária como objeto/fonte de estudo é expressiva. Como sustenta Maria Nazareth Ferreira:

\begin{abstract}
Seu valor é inegável sob o ponto de vista histórico, pela quantidade e qualidade das informações que revela ao pesquisador. Qualidade porque todos os problemas internos à classe, fraquezas, lutas internas, tudo o que acontecia no meio operário era motivo de debates e informações que ganhavam as páginas dessa imprensa; quantidade, devido ao grande número de jornais e revistas publicado, cobrindo todas as regiões do Brasil, onde se destacavam a questão social e as condições de organização da classe trabalhadora ${ }^{23}$.
\end{abstract}

Com efeito, a imprensa operária se coloca como um instrumento documental valioso capaz de promover uma integral reavaliação do processo histórico regional, vista pelo ângulo dos trabalhadores. O estudo dos jornais operários se caracteriza enquanto suporte para inserção de sujeitos que ficaram à margem do veio central da historiografia dominante, como também para transcender as tradicionais representações ideológicas do trabalhador que emergem dos registros oficiais ${ }^{24}$.

${ }^{20}$ DIAS, Ednéa Mascarenhas. A Ilusão do Fausto: Manaus, 1890-1920. Manaus: Editora Valer, 1999.

${ }^{21}$ PINHEIRO, Maria Luiza Ugarte. A Cidade Sobre os Ombros: Trabalho e Conflito no Porto de Manaus (18991925). Manaus: Edua, 1999.

${ }^{22}$ COSTA, Francisca Deusa Sena da. Quando Viver Ameaça a Ordem Urbana: cotidiano de trabalhadores em Manaus, 1915-1925. Dissertação de Mestrado, PUC-SP, 2000.

${ }^{23}$ FERREIRA, Maria Nazareth. Imprensa Operária no Brasil. São Paulo: Ática, 1988, p. 13-14.

${ }^{24}$ PINHEIRO, Maria Luiza Ugarte e PINHEIRO, Luís Balkar Pinheiro (orgs.). Op. cit., p. 9. Os autores argumentam que não só nestes registros oficiais como em outros documentos (jornais que se alinhavam com segmentos dominantes e que acabavam por defender seus projetos e propostas) observa-se um discurso unidirecional que buscava uniformizar a imagem do trabalhador a partir de rótulos depreciativos, entendendo-os como "classes perigosas", e suas ações como "assunto de polícia". Idem, p. 10. 


\title{
A SINGULARIDADE DA IMPRENSA OPERÁRIA
}

\begin{abstract}
Antes, em período histórico de condições diversas, houvera pequena imprensa; desde o século $X X$, porém, há grande e pequena imprensa, e esta se agrupa em dois planos: a que é pequena tão somente por condições materiais, relegada ao interior do país e que em nada perturba a estrutura social, econômica e política dominante (...) e a que agrupa publicações de circulação reduzida e de pequenos recursos materiais, mas que mantém uma posição de combate à ordem vigente e cuja condição deriva dessa posição. Assim, na imprensa, quanto aos órgãos, revistas e jornais, o que existe, agora, é uma imprensa de classe: ou da classe dominante, ou da classe dominada, com todos os reflexos que essa divisão proporciona à atividade dos periódicos e do periodismo ${ }^{25}$.
\end{abstract}

A epígrafe acima estabelece uma classificação dos periódicos tendo por base os grupos que os produziam: periódicos de classes dominantes e classes dominadas. A despeito da divisão bipolarizada e uniforme, característica de um marxismo ortodoxo, Sodré aponta para a ligação dos periódicos a determinados grupos e para a divulgação de suas respectivas ideias e projetos sociais.

Circulando de forma diferente da grande imprensa e demais periódicos, a imprensa operária esteve presente na arena jornalística de diversas regiões brasileiras. Localizando o surgimento da imprensa operária no Brasil no início da década de 1860, Foot Hardman e Victor Leonardi mencionam o fato de que:

Eram pequenos jornais, de tiragem reduzida e de vida geralmente efêmera. Porém, não se pode negligenciar o papel desempenhado por essa imprensa operária no processo de formação do proletariado como classe ${ }^{26}$.

Para entender a produção e difusão da imprensa, e em particular da imprensa operária, é preciso destacar duas questões. A primeira questão se relaciona às transformações econômicas, políticas, sociais e culturais ocorridas no final do século XIX (abolição da escravidão, a proclamação da República, os processos de industrialização, ampliação do mercado interno, imigração etc.) e que conduziram algumas cidades brasileiras a um processo de ampliação da produção e difusão da cultura letrada e impressa. Para Cruz:

\footnotetext{
${ }^{25}$ SODRÉ, Nelson Werneck. História da Imprensa no Brasil. 4ae ed. Rio de Janeiro: Mauad, 1999, p. 323.

${ }^{26}$ HARDMAN, Francisco Foot e LEONARDI, Victor. História da Indústria e do Trabalho no Brasil: das origens aos anos 20. São Paulo: Ática, 1991, p. 103.
} 
Seria principalmente nas últimas décadas do século XIX, surpreendida pela turbulência das transformações sociais, que a cultura letrada e impressa começaria decididamente a avançar para além das elites tradicionais. Nessa época, em ritmo acelerado, no compasso de um modo de vida que exporta capitais e invade rapidamente inúmeros espaços do planeta, a história da formação das metrópoles brasileiras multiplica o tempo e a experiência social ${ }^{27}$.

O avanço da cultura letrada para além dos círculos das elites tradicionais nos remete à segunda questão. Com o desenvolvimento dos segmentos médios urbanos - advogados, médicos, professores, funcionários públicos e outros - ocorre um aumento no número de pessoas que possuíam o domínio da leitura e da escrita. Este processo potencializou a possibilidade de esses grupos viabilizarem impressos para divulgar suas ideias, interesses e projetos.

Esta viabilização se deve ainda a questões técnicas de produção dos periódicos. 0 surgimento e o aumento de mão de obra especializada e a superação da escassez de recursos financeiros e matérias-primas necessárias à feitura das folhas, notadamente em momentos de expansão econômica, contribuíram de forma relevante para a diversificação e variedade da produção. Porém, não se deve com isso pensar que os periódicos nasceram impressos. Muitas folhas começaram a circular manuscritas ou datilografadas. Nos momentos de boom na produção de periódicos (final do século XIX e as duas décadas iniciais do século $X X)$, as folhas artesanalmente produzidas conviveram paralelamente com as impressas.

Com a expansão dos grupos produtores de periódicos, temas relacionados com a cidade e as relações entre os grupos presentes no espaço urbano passaram a ser retratados. Neste sentido,

A cidade intromete-se na imprensa. O crescimento da cidade, a diversificação das atividades econômicas, a ampliação do mercado e o desenvolvimento da vida mundana são incorporados às formas e conteúdos dessas publicações. Através de novas temáticas, personagens e linguagens, o processo social que transforma a cidade passa também a configurar as publicações ${ }^{28}$.

Entre os grupos que se envolveram neste processo de feitura de periódicos estão os operários. No Brasil, em especial nas principais capitais brasileiras, a formação da classe operária ocorreu com o advento da urbanização e da industrialização. Não obstante, como alguns estudos apontam ${ }^{29}$, o surgimento da classe operária deve ser pensado menos como

\footnotetext{
${ }^{27}$ CRUZ, Heloisa de Faria. São Paulo em papel e tinta... Op. cit., p. 43.

${ }^{28}$ Idem, p. 80.

${ }^{29}$ PETERSEN, Silvia Regina Ferraz. “Que a União Operária seja nossa pátria!”. História das lutas dos operários gaúchos para construir suas organizações. Santa Maria: Porto Alegre: UFSM/UFRGS, 2001. BATALHA, Cláudio.
} 
uma relação mecânica e automática entre indústria e operário - este como consequência direta daquela - do que como "fenômeno histórico que unifica uma série de acontecimentos díspares" ${ }^{30}$.

Nesse sentido, como assinala Batalha, pode-se falar de formação da classe operária como "um processo conflituoso, marcado por avanços e recuos, pelo fazer-se e pelo desfazer-se da classe, que surge na organização, na ação coletiva, em toda manifestação que afirma seu caráter de classe" ${ }^{31}$.

A imprensa operária é uma dimensão desta manifestação. Maria Nazareth Ferreira ${ }^{32}$ abordou, numa perspectiva global, este tipo de imprensa externando suas características dificuldades técnicas e financeiras de produção, irregularidade, efemeridade e outros - e sua importância para a politização do operário nacional. Ferreira ainda fez um levantamento sobre os jornais espalhados pelas regiões do Brasil desde o último quartel do século XIX até as duas décadas do século atual. Como salienta a autora:

\begin{abstract}
Apareceram aproximadamente 343 títulos de jornais espalhados pelo território brasileiro. Desse total, 149 títulos encontravam-se no Estado de São Paulo, dos quais 22 foram publicados fora da capital; cem títulos foram editados no Rio de Janeiro, onde apenas sete situavam-se fora da capital; 94 títulos encontravam-se distribuídos por outros Estados, destacando-se o Rio grande do Sul, Minas Gerais, Pernambuco, Alagoas e Paraná ${ }^{33}$.
\end{abstract}

Entretanto, em que pese a significativa relevância da obra de Ferreira, a divisão feita pela autora - imprensa anarcossindicalista (1889-1930), imprensa sindical-partidária (19301964) e imprensa sindical (1964-1986) - para a Primeira República chega a ser arbitrária.

Para além da imprensa anarquista, outros jornais de tendências políticas diversas concorreram entre si pela organização e condução da política operária, sobretudo jornais animados por grupos reformistas. Esta tendência, em algumas regiões brasileiras, como Rio Grande do $\mathrm{Sul}^{34}$ e Rio de Janeiro ${ }^{35}$, eram hegemônicas. Em Manaus, estudos recentes ${ }^{36}$

Formação da Classe Operária e Projetos de Identidade Coletiva. IN: FERREIRA, Jorge, DELGADO, Lucilia de Almeida Neves (org.). O Brasil Republicano Vol. 1. Rio de Janeiro: Civilização Brasileira, 2003.

30 THOMPSON, Edward Palmer. A Formação da Classe Operária Inglesa. Vol. 1. Rio de Janeiro: Paz e Terra, 1987, p. 17.

31 BATALHA, Cláudio. Formação da Classe Operária e Projetos de Identidade Coletiva... Op. cit., p. 173.

${ }^{32}$ FERREIRA, Maria Nazareth. Imprensa Operária no Brasil... Op. Cit..

33 Idem, p. 14.

${ }^{34}$ PETERSEN, Silvia Regina Ferraz. "Que a União Operária seja nossa pátria!". História das lutas dos operários gaúchos para construir suas organizações. Santa Maria: Porto Alegre: UFSM/UFRGS, 2001.

${ }^{35}$ FAUSTO, Boris. Trabalho Urbano e Conflito Social. São Paulo: Difel, 1986. BATALHA, C. O Movimento Operário na Primeira República. Rio de Janeiro: Jorge Zahar Editor, 2000. 
demonstram a força do reformismo no interior do movimento operário. Isto pode ser reforçado pelo número de jornais publicados e que se alinhavam em menor ou maior grau com esta tendência, como é o caso do Gutemberg, Operário, Vida Operária, O Extremo Norte e $O$ Constructor Civil. Porém, antes de abordar a imprensa operária manauara em particular é necessário destacar o surgimento e desenvolvimento dos periódicos em geral.

A ampliação da produção e difusão de periódicos em Manaus enfrentou algumas limitações estruturais e técnicas. Com relação à primeira questão, o baixo nível demográfico das vilas e cidades, o isolamento geográfico por elas vivenciado, o caráter tardio e incompleto da língua portuguesa e a incipiência nos índices de letramento e alfabetização se colocaram como obstáculos à proliferação de periódicos. Além disso, problemas propriamente técnicos como a inexistência de uma mão de obra especializada (sobretudo tipógrafos) e a escassez de recursos financeiros e matérias-primas para a feitura de impressos estiveram presentes ${ }^{37}$.

Com o advento da expansão da economia gomífera parte dessas limitações foi sendo superada. A cidade de Manaus passou ao mesmo tempo por um processo de transformação e crescimento, e de ampliação e diversificação das atividades econômicas. Este processo elevou o nível demográfico, interligou a região do extremo norte a outras regiões do Brasil e do globo (outros países). Porém, a questão do baixo índice de alfabetização e letramento permaneceu. Como essa questão foi superada?

Pinheiro, ao analisar a dinâmica e o avanço dos impressos no Amazonas, uma sociedade marcada ainda pela oralidade, salientou que, "por vezes, a introdução da escrita, menos que desarticular ou sobrepujar o pensamento oral, vê-se apropriada por ele e submetida a seus próprios termos". Desta forma, é preciso perceber não só "as limitações estruturais, mas também as estratégias empreendidas pela cultura letrada para se impor dentro desse contexto cultural adverso" ${ }^{38}$. Dentre as estratégias se apresenta a leitura coletiva realizada nos botequins, bares, clubes, associações de classe, ambiente escolar e nas ruas.

O primeiro jornal que circulou em Manaus foi o Cinco de Setembro em 3 de maio de 1851. Seu diretor e proprietário era o tenente e tipógrafo Manoel da Silva Ramos, que a convite de Tenreiro Aranha montou a primeira oficina tipográfica de Manaus, situada à margem esquerda do igarapé do Espírito Santo (nas proximidades do atual porto de Manaus). Em 1852, após oito meses de existência, seu nome foi substituído por Estrela do Amazonas $^{39}$. O Estrela do Amazonas circulou até 1866. Nesse ano este jornal foi vendido ao português Antônio da Cunha Mendes, que em 9 de julho de 1866 o transformou em $O$

\footnotetext{
${ }^{36}$ PINHEIRO, Maria Luiza Ugarte. A Cidade Sobre os Ombros: Trabalho e Conflito no Porto de Manaus (18991925). Manaus: Edua, 1999. COSTA, Francisca Deusa Sena da. Quando Viver Ameaça a Ordem Urbana: cotidiano de trabalhadores em Manaus, 1915-1925. Dissertação de Mestrado, PUC-SP, 2000.

${ }^{37}$ PINHEIRO, Maria Luiza Ugarte. Folhas do Norte... Op. cit., p. 65-66.

${ }^{38}$ Idem, p. 55.

${ }^{39}$ FREIRE, José Ribamar Bessa (Coord.). Cem Anos de Imprensa no Amazonas Op. cit., p. 57.
} 
Amazonas. Consoante Souza, O Amazonas teve vida longa, chegando até a segunda década do século $X X$, o que era

\begin{abstract}
algo raro entre os jornais, principalmente nesta fase embrionária da imprensa amazonense e de resto no país como um todo caracterizada por uma produção artesanal, realizada em pequenas oficinas em que os serviços gráficos de redação, composição e prensa, eram de responsabilidade quase sempre de um único profissional tipógrafo, geralmente o dono (...). A maioria dos jornais tinha vida efêmera e não chegavam a completar um semestre e muitos ficavam mesmo no seu primeiro mês, como o Vigilante (1859), Checheo (1861), Lei (1867), Actualidade (1874) que não atingiram meio semestre de existência, o terceiro, encerrou-se mesmo no seu segundo número ${ }^{40}$.
\end{abstract}

As características levantadas por Souza remetem ao período que se estende de 1851 (ano de circulação do primeiro jornal do Amazonas) a 1880 (ano em que as exportações da borracha começaram a crescer). Esse período é classificado por Pinheiro ${ }^{41}$ como sendo a primeira fase da imprensa no Amazonas, tendo o ano de 1880 como marco divisório. Após esta data se inicia a segunda fase, marcada pela ampliação, proliferação e diversificação de jornais. Este processo de ampliação e proliferação foi alimentado pelo boom da economia gomífera, que possibilitou não somente o capital necessário para o desenvolvimento de um processo de modernização das oficinas tipográficas (novas tecnologias), como também a oferta de profissionais especializados (tipógrafos) e a ampliação do círculo de produtores e leitores de jornais. Para Souza,

Entre as últimas décadas do século XIX e a primeira do XX, o número de jornais que a cada dia invadiam diversos recantos da capital, sofre um aumento até então jamais registrado. Se na entrada da década de 80 circulavam pela capital pouco mais de vinte impressos, no final desta o número tinha mais do que triplicado, atingindo a cifra de 71 periódicos, mantendo-se estável até a virada do século com 77 jornais para finalmente quase duplicar ao término da primeira década ${ }^{42}$.

Desta forma, a composição do cenário jornalístico entre os anos de 1880 e 1920 engloba os pasquins, cujo foco é a sátira social. A Imprensa Estudantil discutia tanto questões literárias e científicas quanto questões políticas de âmbito local e nacional. As Polyanthéas, espécie de impresso produzido em homenagem a governadores, artistas e instituições políticas e sociais. A Chamada "grande imprensa", composta pelo O Amazonas, Jornal do Comércio, Diário de Notícias, Correio do Norte, Gazeta da Tarde e outros. Por fim,

\footnotetext{
${ }^{40}$ SOUZA, Leno José Barata. Vivência Popular na Imprensa Amazonense: Manaus da Borracha (1908-1917). Dissertação de Mestrado em História. São Paulo: PUC, 2005, p. 73.

${ }^{41}$ PINHEIRO, Maria Luiza Ugarte. Folhas do Norte... Op.cit., p. 62.

${ }^{42}$ SOUZA, Leno José Barata. Vivência Popular na Imprensa Amazonense... Op.cit,. p. 76.
} 
jornais de cunho operário que criticavam a ordem política, econômica, social e cultural vigente. Neste universo, o alvo das investigações é a imprensa operária.

Para abordar a imprensa operária no Amazonas algumas questões se apresentam. A primeira é a própria definição de imprensa operária. De acordo com Maria Nazareth Ferreira, quando se fala em imprensa operária se imagina uma imprensa produzida por operários. Mas isso se a considerarmos do ponto de vista do emissor. Já do ponto de vista do receptor, imprensa operária seria aquela que se dirige, prioritariamente, ao público operário e, do ponto de vista da mensagem (conteúdo), pode-se considerar como imprensa operária aquela cuja temática básica são os problemas dessa classe ${ }^{43}$.

Para Ferreira é preciso ainda levar em conta outros elementos. O primeiro deles é a existência de uma razoável quantidade de publicações que, apesar de não serem produzidas por operários, e sim por elementos de outras classes sociais (professores, advogados etc.), visam a esse público, abordam uma temática operária e expressam, de uma maneira ou de outra, as reivindicações do operariado. Outra questão que se impõe é a articulação existente entre o partido, o sindicato e o jornal. Esses três elementos, suporte da luta da classe trabalhadora, devem ser considerados, sobretudo o papel atribuído ao jornal, muito embora não se possa reduzir a imprensa operária à imprensa sindical, pois a primeira possui um alcance muito maior. Por fim, a imprensa operária não pode ser avaliada desvinculada do movimento operário, pois ambos estão inter-relacionados através das lutas da classe trabalhadora na construção de sua história.

Desta forma, o conjunto de jornais operários publicados em Manaus caracteriza-se enquanto tal pelo fato de se direcionarem à classe trabalhadora e por serem produzidos e difundidos em seu nome ${ }^{44}$.

Em segundo lugar, os termos "operário" e "imprensa operária" devem ser relativizados. No Amazonas, esses termos, que geralmente remete ao trabalhador fabril, são utilizados em sentido mais amplo, abarcando o conjunto dos trabalhadores urbanos. Por força disso, "um termo mais de acordo com as especificidades regionais para designar os periódicos (...) seria o de imprensa de trabalhadores" ${ }^{45}$. Entretanto, a opção pela utilização dos termos operário e imprensa operária se deve à frequente utilização deles nos jornais operários.

43 FERREIRA, Maria de Nazaré. Imprensa Operária no Brasil. São Paulo, Ática, 1988.

${ }^{44}$ Até hoje foram identificados os seguintes títulos (até 1930): O Restaurador (1890), Gutenberg (1891-1892), Operário (1892), Tribuna do Caixeiro (1908), Confederação do Trabalho (1909), O Marítimo (1911), Recordação - Sociedade Protetora das Artes Gráficas (1911), Marinha Mercante (1913), A Lucta Social (1914 e 1924), Folha Marítima (1916), O Constructor Civil (1920), O Extremo Norte (1920), Vida Operária (1920), O Primeiro de Maio (1928). Cf: PINHEIRO, Maria Luiza Ugarte e PINHEIRO, Luís Balkar Sá Peixoto. Imprensa Operária no Amazonas... Op. cit., p. 11.

${ }^{45}$ PINHEIRO, Maria Luiza Ugarte e PINHEIRO, Luís Balkar Sá Peixoto. Imprensa Operária no Amazonas... Op. cit., p.14. 
Observando o conjunto de jornais operários publicados em Manaus, percebe-se a presença de duas grandes correntes políticas: o Anarquismo e o Socialismo Reformista. Representando a primeira corrente mencionada, encontra-se o jornal anarcossindicalista $A$ Lucta Social (1914 e 1924). Por outro lado, os jornais Gutenberg (1891), Operário (1892), O Constructor Civil (1920), O Extremo Norte (1920) e Vida Operária (1920) se aproximam, embora existam alguns pontos de divergências entre eles ${ }^{46}$, todos do Socialismo Reformista.

P. Albert e F. Terrou dizem que "não é fácil delimitar o objeto da história da imprensa". Eles destacam quatro pontos de dificuldades de delimitação, entre eles a questão da diversidade de seus órgãos e a consequente nebulosidade da unidade do conjunto ${ }^{47}$. Para os autores,

\begin{abstract}
Já no século XVII a noção de imprensa periódica abrangia uma massa muito díspar de publicações e, nos séculos seguintes, seus tipos e categorias se diversificaram a tal ponto que muitas vezes a variedade e multiplicidade dos títulos acabam mascarando a unidade do conjunto.

Além das características comuns a todas as publicações - essencialmente o estatuto jurídico, os dados técnicos de sua fabricação, os dados econômicos de sua exploração e o aspecto formal do todo -, a originalidade do conteúdo e a especificidade do público de cada título constituem um obstáculo ao estatuto global da imprensa. O historiador da imprensa deve tentar conciliar o estudo individualizado de cada título com a apresentação do mundo da imprensa em seu conjunto $^{48}$.
\end{abstract}

Com efeito, no decorrer das décadas iniciais do século XX a diversidade dos órgãos de imprensa é inconteste, não só no seu conjunto (pasquins, imprensa estudantil, grande imprensa e outros) como também em cada grupo específico, em especial a imprensa operária. Desta forma, a opção pelos jornais destacados anteriormente se deve ao fato de melhor delimitar o objeto de estudo proposto e compreender o papel desempenhado pelas chamadas "folhas operárias".

${ }^{46}$ Como exemplo, menciona-se o fato de que os jornais Vida Operária e O Extremo Norte não negam o regime republicano, o processo político e eleitoral, e o fato de que consideram três elementos importantes como suporte da luta operária: a organização (associação), o partido político e o jornal. Entretanto, divergem quanto às formas de organização e a natureza do partido operário. Estes pontos de convergência e divergência entre ambos são abordados no capítulo 3.

${ }^{47}$ Os outros três são: (1) não se pode construir uma história da imprensa sem uma constante referência à evolução geral das sociedades, (2) os limites do domínio da imprensa periódica são imprecisos tanto no que se refere às demais produções impressas quanto em relação aos outros meios de informação, fruto do avanço tecnológico como o cinema no final do século XIX e o rádio nos anos vinte do século passado, e (3) a característica de "arquivos do cotidiano" e a consequente função derivada de fonte dos historiadores. ALBERT, P. e TERROU, F. História da Imprensa. São Paulo: Martins Fontes, 1990, p. 1-2.

${ }^{48}$ Idem. 
Neste sentido, o Gutemberg foi o primeiro jornal operário a circular na arena jornalística amazonense, em 15 de novembro 1891, tendo como subtítulo "Periódico Noticioso e Litterario" e como divisa "um por todos e todos por um". Sua oficina e redação funcionavam na Praça 5 de setembro, no 42 . Com o formato de $41 \times 29 \mathrm{~cm}$ foram editados 25 números, dos quais apenas três (n.ㅇs 1, 19 e 25) se encontram microfilmados em arquivos localizados no Estado do Amazonas (Biblioteca Pública, Museu Amazônico, IGHA e LHIA).

Este periódico era vendido avulso por 60 réis e por assinaturas trimestrais ao preço de $3 \$ 000$ para a capital e $4 \$ 000$ para o interior. Interessante destacar que no seu primeiro título o jornal trazia o recado de que a venda só se daria avulso e não por assinaturas. Ao que parece houve dificuldades no que tange à venda avulsa, sendo aceita e oferecida a venda por assinaturas. Possuía quatro páginas e três colunas. Nos títulos de no 1 e no 19 as páginas eram preenchidas basicamente com matérias e informações, não havendo imagens nem anúncios e propagandas. Quanto a estes últimos só vão aparecer na última página do no 29 do periódico e sem imagens, apenas com texto.

Como estava ligado à classe dos tipógrafos, a distribuição para esta categoria era gratuita assim como também espaços na coluna do jornal para a defesa de seus direitos políticos e sociais. Segundo o próprio jornal, as estações de venda se localizavam nas tabacarias, mercado público e por todos os círculos da cidade. Quanto à tiragem, no primeiro número o jornal indica a cifra de 1.000 exemplares publicados. O corpo de redação era composto por Francisco Alves Medeiros, Izidoro Vieira, V. Galvão, R. Vasconcellos, Antônio Leão e Marcellino da Exaltação Fernandes.

Comparando os três números existentes percebem-se algumas mudanças. A primeira é o subtítulo. Enquanto no número de apresentação o jornal indicava como subtítulo Periódico Noticioso e Litterario, no número 19, publicado em 1ㅇ de maio de 1892, ele foi modificado para Órgão do Partido Operário. Este fato evidencia a constituição e fundação de um Partido Operário no Amazonas nos anos iniciais da Primeira República Brasileira. A segunda mudança está no corpo de redação: Francisco Alves Medeiros, R. Vasconcellos e Izidoro Vieira deixaram de integrar este corpo, sendo incorporado outro, de nome Marcellino da Exaltação Fernandes, que acabou assumindo como redator-chefe.

As matérias e informações veiculadas pelo Gutemberg eram variadas. Falava-se de precários serviços de limpeza de rua, da péssima iluminação pública, da carestia de vida, da perseguição política, além de salientar a importância de um órgão de imprensa e de um partido operário para a defesa da classe tipográfica e operária em geral. Sobre a constituição do partido operário, o jornal afirmava:

Em todos os Estados adeantados da União Brazileira está crescendo e solidamente firmado o Partido Operário.

Entre nós, somente o único Estado onde faltava ser organisada essa aggremiação de artistas que procuram fazer valer a sua independência e a sua liberdade, acaba de ficar definitivamente creado e pronpto; por conseguinte, a trabalhar em prol 
d'aquilo que o verdadeiro artista sempre, acima de tudo, deve procurar a sua independência.

Acaba o Partido Operário do Amazonas, de entrar no caminho do progresso e da prosperidade, ajudado, estamos, convictos d'isto por todos os artistas e operários, sem distincção de classe e nacionalidades, tendo todos em mira o engrandeciemnto do mesmo partido ${ }^{49}$.

O Operário se apresentou na arena jornalística em 12 de dezembro de 1892. De formato $37 \times 52 \mathrm{~cm}$, com dois números editados, declarava-se o sucessor do Gutemberg ${ }^{50}$. Tinha como redatores Izidoro Vieira e Thomas Porto, e como colaborador Santos Porto. Era vendido avulso pelo preço de 300 réis, e por assinaturas trimestrais no valor de $5 \$ 000$ para a capital e $6 \$ 000$ para o interior. Tinha publicação semanal e sua oficina e redação eram as mesmas do Gutemberg.

O Operário possuía quatro páginas e quatro colunas. Nas duas primeiras páginas e metade da terceira eram distribuídas as notícias e informações, e nas restantes, propagandas e anúncios. Com relação às notícias, as críticas sobre os serviços urbanos continuam. A novidade está em uma coluna específica denominada "Movimento Social". Nela há uma espécie de análise do movimento operário no mundo moderno.

Quanto aos anúncios e propagandas aparece, além de textos recomendando serviços médicos e produtos de determinados estabelecimentos comerciais - Alfaiataria do Centro do Mundo Elegante, Sapataria Amazonense, Armarinho Papa Abroz, Casa de Armador e outros -, uma imagem de mulher com ramalhetes de flores (em propaganda da casa Mascotte). Essa imagem era relativamente simples, mas já figurava no jornal.

Outro jornal operário que se fez presente neste momento foi $O$ Constructor Civil. Publicado em 1920, tinha como subtítulo Orgam da Associação de Classe das Quatro Artes de Construção Civil. Seus colaboradores eram José Monteiro, J. Ultramar e outros que assinavam pelas letras iniciais como M. J. S. e A. F. Seu formato era de $25 \times 37 \mathrm{~cm}$ e possuía quatro páginas e três colunas. O jornal foi publicado em uma data comemorativa, o aniversário da Associação das Quatro Artes, em 5 de janeiro de 1920. Talvez por isso não tenha propagandas. Quanto aos artigos produzidos, destacavam a importância da associação para os operários. Como exemplo se pode citar o artigo intitulado "A Minha Associação":

Mais um anno! O segundo de lucta em prol da emancipação operária e contra os seus terríveis inimigos.

\footnotetext{
${ }^{49}$ Gutenberg, no 19. Manaus, 1ㅇ de maio de 1892.

${ }^{50}$ Em artigo intitulado "Reaparecemos", o jornal externa esta linha: "O reaparecimento do órgão das classes operárias, sob o nome Operário não é, por certo, um facto que cause surpresa no seio da opinião. Os graves acontecimentos que se desdobraram no nosso meio e motivaram a suspensão da publicação dos jornais desta capital, excepção feita do órgão oficial..." Operário. Manaus, 12 de dezembro de 1920.
} 
Relembra-nos o dia de hoje, todo um passado de sacrifícios, não só contra o inimigo commum, mas também contra a má vontade dos que podendo ser livres, preferem o degradante papel de escravos ${ }^{51}$.

O Extremo Norte apareceu no mesmo ano que o jornal $O$ Constructor Civil. Encontram-se nos arquivos ${ }^{52}$ seis números microfilmados, sendo o primeiro de 8 de abril de 1920, e o último de 24 de outubro de 1920. Tinha o formato $30 \times 43 \mathrm{~cm}$, quatro páginas e quatro colunas, onde eram distribuídos, na última página, propagandas e anúncios, e nas três primeiras, artigos e notícias. A sua publicação era semanal e, com relação ao preço por que era vendido, não há informações.

Tinha como subtítulo União, Labor e Liberdade. Sua redação localizava-se à Rua Municipal, no 239. No lado superior direito do jornal se encontram impressos os termos "Propriedade de uma empresa". Entretanto, percebe-se que a produção do jornal se sustentava menos por se constituir enquanto empresa do que pela divulgação e colaboração dos operários.

Certamente ninguém ignora que a crise do papel, vae se aggravando cada vez mais, o que dificulta de maneira assustadora a publicação do nosso jornal e não temos recursos outros que não sejam os que nos dá o proletariado em geral, pedimos, aos companheiros que nos auxiliam, attender ao nosso camarada Manoel Ferreira, que se acha em actividade na gerência do Extremo Norte ${ }^{53}$.

O jornal tinha como gerente Manoel Ferreira. Seus redatores e colaboradores eram Nicolau Pimentel, Raul Braga, Themístocles dos Reis, Lyra Amorim, Joaquim Carneiro, Cursino Gama, Jayme de Medeiros, Sergius Vinicius, Athanásio Mecena, Manoel Sérvulo, Francis, J. Mellino e José Florindo. Pelas colunas do jornal $O$ Extremo Norte eram veiculadas denúncias contra a atuação das empresas estrangeiras que administravam os serviços urbanos da cidade, as relações de trabalho, a jornada de trabalho, a falta de pontualidade nos pagamentos, além de um conjunto de notícias sobre o movimento operário em algumas regiões do Brasil e do mundo. Também não ficam de fora as discussões sobre algumas correntes político-ideológicas que atingiam o movimento operário.

No que tange aos anúncios e propagandas, estes ficavam em uma pequena parte da terceira página e em toda a última página. Eles falavam dos cinemas Odeon e Polytheama, de farmácias, alfaiatarias e serviços de barbearia, médicos e outros.

Já o jornal A Lucta Social circulou em Manaus no ano de 1914, graças à "iniciativa de um grupo de trabalhadores gráficos, articulados com a Confederação Operária Brasileira

\footnotetext{
${ }^{51}$ O Constructor Civil, no 1. Manaus, 5 de janeiro de 1920.

${ }^{52}$ Assim como o Gutemberg, o Operário, O Constructor Civil e o Extremo Norte se encontram microfilmados na Biblioteca Pública, Museu Amazônico, IGHA e no LHIA.

${ }^{53}$ O Extremo Norte, no 37. Manaus, 20 de setembro de 1920.
} 
(COB), fundada em 11 de setembro de $1910^{\prime \prime 54}$. Ao contrário dos jornais acima citados, de orientação reformista, $A$ Lucta Social era de orientação anarcossindicalista.

Este jornal teve duas fases. Na primeira, no ano de 1914, seu redator-chefe era Tércio Miranda. Tinha publicação mensal. Seus dois primeiros números foram distribuídos gratuitamente, sendo os seguintes vendidos a 200 réis. Os colaboradores desta primeira fase eram Joaquim Azpilicueta, Virgílio de Sá, José da Mota Veiga, Carlos Malato, F. Cavalcante e Virgílio de Sá. Algumas publicações de caráter doutrinário eram transcrições de obras de pensadores anarquistas. Quanto ao formato, era de

\begin{abstract}
22×30 cm. O número de páginas apresentou variações importantes, provavelmente em função da quantidade do material produzido pelos redatores ou dos artigos solucionados para transcrição. Assim, o primeiro número saiu com nove páginas, enquanto os dois números seguintes recuaram para oito. Uma retração maior apareceu no número quatro, com o jornal reduzido à metade de seu tamanho inicial (quatro), voltando a ampliar o número de páginas para seis em seu último número ${ }^{55}$.
\end{abstract}

Os temas abordados obedecem a uma estrutura discursiva lógica que vai "da estrutura e dinâmica das sociedades, passando pela identificação dos conflitos de classe e formas de organização do trabalho, até a explicação da consciência de classe do operariado, a ampliação de suas lutas e a necessária transformação revolucionária da sociedade" ${ }^{56}$.

Na segunda fase o redator-chefe era J. Nicoláo Pimentel. Como colaborador aparece somente Gervasio Leal. Esta fase reflete o momento político vivido pelo Amazonas. O Movimento de 1924 ganha as páginas e as colunas do periódico. Da mesma forma, as críticas direcionadas à gestão Rego Monteiro foram registradas.

Esta imprensa operária ${ }^{57}$, que no Amazonas surgiu a partir da publicação do Gutemberg em 15 de novembro 1891, expressa as diversas tendências políticas e ideológicas presentes no seio do movimento operário amazonense. Não obstante, em que pese esta diversidade - que éenriquecedora do ponto de vista das propostas de participação política num ambiente em que a exclusão política e social era significativa ${ }^{58}$-, é preciso salientar que

\footnotetext{
${ }^{54}$ PINHEIRO, Maria Luiza Ugarte. Folhas do Norte... Op. cit., p. 154.

${ }^{55}$ Idem, p. 156.

${ }^{56}$ Idem, p. 157-158.

${ }^{57}$ Não foram abordados alguns jornais como O Restaurador (1890), Tribuna do Caixeiro (1908), Confederação do Trabalho (1909), O Marítimo (1911), Recordação - Sociedade Protetora das Artes Gráficas (1911), Marinha Mercante (1913), Folha Marítima (1916) e O Primeiro de Maio (1928). Esta opção se deu, como já foi registrado, para melhor delimitar o objeto de estudo proposto e compreender o papel desempenhado pelos jornais operários.

${ }^{58}$ Neste período imperava, no campo político, um liberalismo excludente sustentado pelas forças políticas ligadas ao universo cafeeiro. Uma República ortodoxa em termos de política financeira, e conservadora em
} 
os aspectos econômicos, políticos, sociais e culturais que se fazem presentes no seio desta imprensa contribuem para caracterizá-la no interior do periodismo local.

Assim, os diretores, redatores-chefes e colaboradores da imprensa operária do início do século XX, identificando-se com a classe operária amazonense, expressaram suas tradições, aspirações e conspirações, num contexto de transformações socioeconômicas, políticas e culturais produzidas pela expansão da economia gomífera ${ }^{59}$.

Esta expansão econômica que ocorreu entre os anos de 1880 e 1920 produziu um aumento demográfico significativo. Porém, as levas de trabalhadores migrantes e imigrantes que chegavam a Manaus não eram totalmente absorvidas pelas atividades econômicas desenvolvidas no espaço urbano. Como consequência desse processo, os trabalhadores excluídos do mercado de trabalho formal, e mesmo aqueles que foram incorporados de forma precária, tiveram de enfrentar problemas diversos como moradia, alimentação, saúde, baixos salários e outros. Este quadro de preocupações e insatisfações, associado ao processo de proliferação de ideias de crítica social, contribuiu para a emergência de movimentos contestatórios. Deste modo, elementos que antes inexistiam ou que se faziam presentes de forma tímida, passaram a se tornar frequentes. Manifestações de protestos, greves, passeatas e demais conflitos de caráter de classe passaram a fazer parte do cotidiano amazonense. Não se pode deixar de mencionar as diversas tentativas de criação de associações de classe e de um partido operário.

Além desse quadro socioeconômico, o avanço mais geral da imprensa no Amazonas acabou influenciando de forma direta o surgimento da imprensa operária, não só por conta da proliferação de tipografias e de profissionais envolvidos com a feitura dos jornais - os gráficos $^{60}$-, como também pela nova linguagem que se apresentou, capaz de unir interesses comuns e potencializar a atuação de grupos até então incapazes de se fazer ouvir no seio da sociedade.

Como parte integrante da crítica social produzida naquele contexto de expansão da goma elástica, a imprensa se dinamiza e avança, numa sociedade marcada ainda pela oralidade. É neste universo de transformações e inseguranças que os homens que se envolveram na produção dos jornais operários vão atuar e desenvolver uma luta política em busca de melhores condições de vida para os trabalhadores.

Do ponto de vista econômico não devia ser fácil manter em circulação um jornal operário. Os recursos eram escassos, e para agravar a situação, o patrocínio de terceiros era

termos de participação política. Cf.: CASTRO GOMES, Ângela de. A Invenção do Trabalhismo. 2o ed. Rio de Janeiro: Relume Dumará, 1994.

${ }^{59}$ PINHEIRO, Maria Luiza Ugarte e PINHEIRO, Luís Balkar Sá Peixoto. Imprensa Operária no Amazonas... Op. cit., p. 9.

${ }^{60}$ A categoria dos gráficos assumiu um lugar de destaque e pioneirismo no interior da imprensa operária. Esta condição se deu por conta do domínio das técnicas de impressão e da condição de saber ler e escrever, uma vez que a ampla maioria dos trabalhadores brasileiros era constituída de iletrados. Nesse sentido, desde cedo, os gráficos se destacaram no processo de organização e conscientização da classe operária, criando jornais e associações sindicais. Idem. 
praticamente inexistente. Porém, em que pesem as dificuldades advindas do processo de confecção dos jornais destinados à classe operária, os diretores e colaboradores procuravam, por meio de diversos mecanismos, mantê-los em circulação. Entre esses mecanismos, destaca-se o pedido de colaboração direta ao operário, que era convocado enquanto elemento principal para garantir a sobrevivência das folhas.

Novamente voltando a esse mesmo assumpto, o nosso companheiro Luz disse que para esse dito fim, preciso se fazia, que cada operário à medida de seus esforços, também concorressem com o necessário auxílio para a manutenção da Vida Operária. Jornal das classes proletárias e propositadamente fundado nesse gênero para viver do operariado e para o operariado... ${ }^{61}$

Nesse sentido, muitos artigos foram produzidos com a preocupação de externar ao público-alvo - o operário - a importância de se ter um instrumento de imprensa que se posicionasse em seu favor e que defendesse questões relacionadas ao seu viver. O jornal e seu papel de defesa da causa operária eram destacados, ao mesmo tempo que se falava das consequências que poderiam advir a partir da ausência desses órgãos. Portanto, a orientação no sentido de externar a permanente necessidade de um órgão exclusivo do operariado amazonense estava presente nas colunas de quase todos os jornais operários.

A produção deste tipo de veículo de comunicação se dava de diferentes formas. Conforme Pinheiro, o mais frequente era a produção de jornais operários nas tipografias das agremiações sindicais mais organizadas, como nos indicam os exemplos do Gutemberg e do seu sucessor, o Operário, ambos saídos das oficinas da Associação dos Artistas Gráficos, então em processo de formação e cuja redação e oficina funcionaram na Praça 5 de Setembro. Em segundo lugar, parte desses periódicos amazonenses foi produzida nas oficinas gráficas dos "grandes jornais", em grande medida, com a permissão dos proprietários. Por último, alguns gráficos disponibilizavam de forma clandestina as prensas patronais, fazendo surgir, mesmo que por um curto período de tempo, algum jornal ${ }^{62}$.

Os jornais operários produzidos em oficinas próprias carregam consigo as marcas da presença de técnicas artesanais de produção. Esta presença está materializada na estrutura e diagramação. Este caráter artesanal de produção pode ser explicado pelo alto custo da compra e manutenção das modernas máquinas de linotipo, o que acabava tornando a sua utilização um empreendimento difícil para esses grupos. Com efeito, a irregularidade das publicações acompanhava esses jornais. Alguns apareciam, desapareciam e reapareciam tempos depois com outra configuração. Outros traziam em seu formato as marcas dessas dificuldades, saindo, algumas vezes, em menor tamanho.

\footnotetext{
${ }^{61}$ Vida Operária, no 1. Manaus, 8 fevereiro de 1920.

62 PINHEIRO, Maria Luiza Ugarte. Folhas do Norte... Op. cit., p. 128-173.
} 
Em virtude dos diversos entraves que desde o segundo número vem tendo este nosso jornal, de maneira nenhuma nos foi possível dal-o no Domingo ultimo, attendendo a impossibilidade da sua confecção na officina de onde foi o mesmo publicado. Porém, muito embora saia hoje o Vida Operária em menor tamanho, mesmo assim encontrarão os nossos leitores um regular número de matérias em assumptos diferentes ${ }^{63}$.

No caso do Constructor Civil, em seu primeiro número observa-se que a possibilidade de futuro desaparecimento era algo presente, e por isso os editores alertam que "se não ficarmos n'este número único, será o nosso programma defender e orientar o operariado em geral, e os da construcção civil em particular" ${ }^{64}$. Mais que proféticos, uma vez que o Constructor Civil tirou apenas esse número, os editores estavam apenas dando mostra de sua plena consciência na grandiosidade da tarefa de se publicar uma folha operária.

Além das dificuldades de financiamento tipográfico, o esforço para ter acesso aos materiais necessários à feitura dos jornais parece ter sido significativo. O Extremo Norte, em seu número 17 não deixou de registrar em suas colunas esse esforço, sobretudo em 1920, quando o jornal publica um artigo que trata do aumento do preço do papel e da falta de recursos, elementos que complicavam a sustentação de sua publicação.

Do ponto de vista político, a imprensa operária permanentemente se colocava como um instrumento de conscientização, mobilização e luta dos trabalhadores. Em suas colunas se identificam denúncias sobre as condições de trabalho (jornada de trabalho extensa, falta de segurança nos locais de trabalho, demissões arbitrárias, penalidades e multas etc.), condições de vida (carestia dos gêneros alimentícios, aluguel, estado sanitário, escolarização etc.), a opressão patronal e a exclusão social.

... no dia 10 de janeiro último o conductor chapa 13, Luiz Ventura da Silva, na occasião em que procedia a cobrança, perdendo o equilíbrio, foi cuspido violentamente ao chão, recebendo forte pancada e diversas escuriações, prostrando-o sem falta durante todo o dia. Pois bem. O director da Companhia ou quem quer que fosse, mandou recolher o chapa 13 à Beneficente Portugueza, arbitrando-Ihe o salário de 5 horas de trabalho durante o tempo que estivesse em tratamento. Ora, sabem os nossos companheiros qual foi o resultado dessa amabilidade da Tramways? Lá vae.

Logo que o nosso companheiro Luiz Ventura voltou ao trabalho o gerente mandou que lhe fosse descontada mensalmente uma certa importância até final amortisação das despezas feitas na beneficente.

Agora perguntamos nós:

Onde está a lei que regula o accidente de trabalho? ${ }^{65}$

\footnotetext{
${ }^{63}$ Vida Operária, no 3. Manaus, 24 de fevereiro de 1920.

${ }^{64}$ O Constructor Civil, no 1. Manaus, 5 de janeiro de 1920.

${ }^{65}$ Vida Operária, no 7. Manaus, 21 de março de 1920.
} 
Na citação acima, destacada como exemplo, a denúncia é direcionada a dois alvos. Além de criticar a postura da empresa concessionária dos serviços de bonde e energia elétrica em Manaus por não ter arcado com as despesas de seu empregado, contesta-se também a posição do Estado com relação ao não cumprimento da lei de acidente de trabalho, elaborada em 1919. As empresas procuravam constantemente burlá-la e, ao que parece, havia uma preocupação quanto à ausência de fiscalização e intervenção por parte do Estado na questão. Percebe-se que as matérias publicadas nesses periódicos possuem um caráter crítico e contestatório ${ }^{66}$.

A estratégia construída, defendida e difundida pela maioria dos jornais operários, e considerada capaz de assegurar aos trabalhadores melhores condições de vida e trabalho, estava intimamente ligada ao enfrentamento das questões organizacionais. A organização dos trabalhadores era vista como um instrumento sumamente importante para a luta social e política, como se pode observar no panfleto (ao lado) que os trabalhadores faziam circular na cidade.
IMAGEM 2:

MANIFESTO A FAVOR DA ORgANIZAÇÃo OPERÁRIA



Fonte: "Panfletos Operários" - Acervo Digital (LHIA).

Nesse sentido, duas questões aparecem como fundamentais: o debate e a difusão de ideias e o processo de organização dos trabalhadores. É inegável o papel desempenhado

66 “A novidade principal dos jornais operários, no entanto, não estava na técnica, mas no conteúdo por eles veiculado. De suas páginas emergiam temas e questões que foram tratados de uma maneira extremamente diferenciada do formalismo e refinamento estilístico pretendidos pelos jornais barés. O conteúdo político (e mesmo panfletário) das matérias, a crítica lancinante do mundo social, o tom acentuado de denúncia e o pragmatismo das propostas apresentadas foi a tônica". PINHEIRO, Maria Luiza Ugarte. Folhas do Norte... Op. cit., p. 133. 
pela imigração com relação à difusão e ao debate de um conjunto de ideias de crítica social. Estas ideias se fizeram presentes em Manaus com a vinda de portugueses, espanhóis, italianos e outros estrangeiros e, associadas ao universo de insatisfações produzido pelo quadro socioeconômico e político presente na região, contribuíram para a emergência de um cenário político novo para o Amazonas. Consoante Pinheiro,

Ao abrir as portas do país à imigração européia, o Estado brasileiro não se deu conta, pelo menos de imediato, de que estaria recebendo também pessoas que, em maior ou menor grau, estavam articulados com o processo cruento de luta e conscientização dos trabalhadores e cujo movimento, cada vez mais denso em toda a Europa, mantinha-se em contato direto com propostas políticas as mais diversas. Muitas dessas propostas, como o socialismo (em suas diversas matizes) e o anarquismo, eram identificadas e especialmente dirigidas à classe operária, representando um risco efetivo para a manutenção da estrutura capitalista ${ }^{67}$.

Ainda segunda a autora, com o ingresso dos primeiros imigrantes, Manaus acolheu também uma gama de militantes anarquistas e socialistas que, desde cedo, procuraram dar vazão às suas convicções políticas, qualificando tensões e lutas que começavam, timidamente, a se esboçar. Mesmo antes de as primeiras grandes manifestações de trabalhadores ocorrerem em Manaus, esforços organizativos ligados ao ideário socialista vigente já se faziam notar através da montagem dos jornais operários, da criação de agremiações sindicais e até mesmo através da criação de um partido político para os trabalhadores, em 1891.

Em que pesem as diferenças existentes entre os jornais operários de orientação reformista e anarquista, uma questão era ponto comum: a importância de os trabalhadores se organizarem em prol de melhores condições de vida e trabalho. Nesse sentido, a organização dos trabalhadores era vista como essencial para empreender movimentos visando mudanças e melhorias.

Mas, como oppormo-nos a estas condições, como obtermos a melhoria de nossa situação, forçando o capital a concedel-as? É bem justo pedirmos, mas o operariado pedindo sozinho e desamparado do apoio de seus companheiros de classe, fica em situação inferior ao patrão. O medo de perder o seu trabalho tiraIhe a coragem de protestar ou pedir. É certo que um operário só, ou os operários de uma só fábrica izolada das outras, não tem meios de defender-se, pois o patrão é quem pode exigir e dictar as condicções. Recuzando o pedido de seus operários, o patrão está certo da victória, porque as necessidades de manter a família, e a própria fome, os forçarão, em poucos dias, a capitulação ao trabalho. De facto, o patrão pode registar longo tempo; o operário só, não. Os recalcitrantes são substituídos facilmente mas trabalho novo é difícil de encontrar, porque o patronato fica os conhecendo como rebeldes.

${ }^{67}$ Idem, p. 130. 
Desta situação nasceu a necessidade das associações (...) a associação, nós bem o sabemos, dá ao operariado cohesão e meios de pedir, e de exigir, se necessário for resistindo por longo tempo, pois a associação solidariza os operários (...). Assim, os patrões perdem as vantagens de tratar com um só operário, fraco e izolado, e serão obrigados a tratar com a associação, tão forte como elles ${ }^{68}$.

Eram constantes as tentativas de esclarecimentos acerca da importância da organização em torno de sociedades operárias. Caso contrário apontava-se para as dificuldades advindas do processo de enfrentamento contra as "imposições" e os "desmandos" do patronato e do Poder Público, uma vez que, com a falta de organização, as possibilidades de intervenção eram mínimas.

Com efeito, o discurso presente no jornal operário se localiza no contraponto ao universo patronal e a outras formas de poder constituído. Daí que para o jornal operário apareça como óbvia a tarefa de "trabalhar com todas as nossas forças ao lado daquelle que nos garanta a queda do patronato e [em favor da] a regulamentação entre Capital e Trabalho" ${ }^{69}$.

Caminhando na contramão do poder dominante, a imprensa operária e seus colaboradores passaram a ser fortemente vigiados e, em inúmeras oportunidades, a defesa de um mundo justo e humano lhes custou caro. A repressão, empastelamentos, intimidações, prisões e agressões físicas estiveram presentes em seu cotidiano ${ }^{70}$.

A efemeridade dos jornais operários é fruto deste universo conflituoso e tenso em que eles estão inseridos. Entretanto, somente a repressão não é suficiente para explicar tal efemeridade. Como mencionado anteriormente, as dificuldades de financiamento do trabalho tipográfico e o acesso aos materiais necessários a sua feitura contribuíram fortemente para esta situação.

Do ponto de vista social, além dos elementos que possibilitam adentrar no universo de atuação profissional dos operários - espaço de trabalho, instrumentos utilizados na realização das atividades laborais, horário, relações de trabalho e outros -, identifica-se nos jornais a construção de uma identidade e de uma autoimagem que são também reveladoras da situação operária no interior da sociedade vigente. Embora existissem controvérsias entre as diversas correntes político-ideológicas quanto à forma de organização e atuação política dos trabalhadores em busca de melhores condições de trabalho e vida, a crítica destinada ao lugar ocupado por este operário na sociedade contemporânea está presente nos discursos construídos pelo conjunto dos jornais.

${ }^{68}$ O Extremo Norte, no 19. Manaus, 20 de maio de 1920.

${ }^{69}$ Vida Operária, no 17. Manaus, 6 de junho de 1920.

70 "Se existe circumscripções deste paiz colosso uma nesga onde o operário solfra os reveses da indifferença dos poderes, certamente esta circumscripções é o Amazonas. O operário aggremiado era considerado "indesejável". As associações de classe eram fechadas pela polícia e os seus dirigentes insultados por Mário Monteiro que alem de ameaçal-os de extermínio, trancafiava-os no xadrez". A Lucta Social, no 7. Manaus, 10 de agosto de 1924. 
O operário é quem forja, amolda e faz, e a burguesia [se] senhoria deste feito.

O operário funde e rebate o arado, e outro sulca a terra; o capitalismo esconde-lhe a grandeza $^{71}$.

Os jornais operários frequentemente associavam o trabalho desenvolvido pelo operário à produção de riquezas materiais. Ao contrário dos discursos oficiais em que o trabalho também assumia, entre outras, esta função, as injustiças sociais não eram escondidas. Neles apareciam artigos que explicitavam a falta de acesso do operário às riquezas produzidas por ele próprio.

\begin{abstract}
Sabeis p'ra que servem essas palavras amenas, bonitas, que os burgueses empregam em seus livros, em seus jornais, nos seus discursos, enfim? Servem para enganar-nos, porque desse modo elles não trabalham e querem que nós produzamos tudo do que eles carecem, fazendo-nos ver que o trabalho é uma virtude e que nós temos o dever de trabalhar até morrer, emquanto elles se divertem nos lupanares immundos, desviando-se por completo da prática de tal virtude, isto é - do trabalho.

Assim, pois, camaradas, é chegada a hora de ajustar contas com elles, nós que tudo produzimos (...) e nada possuímos; é necessário, é indispensável pois, que todos os que vivemos do trabalho pensemos ao menos cinco minutos no nosso futuro e no de nossas famílias ${ }^{72}$.
\end{abstract}

Nestes periódicos, os operários aparecem como "a força motora" do mundo contemporâneo, o "fator do progresso", o braço que influi no "dinamismo comercial, agrícola e industrial de um povo"; enfim, como detentor de um papel essencial, que não é reconhecido pelos setores dominantes, nem no interior das sociedades. Desta forma, a construção de uma autoimagem positiva - o que explica as propagandas de combate ao álcool e aos jogos - dava-se no sentido de se construir este reconhecimento, a fim de garantir um espaço que possibilitasse a participação no campo político.

Além disso, havia em alguns desses jornais, como no A Lucta Social, a presença de um nível significativo de conscientização, identificação e pertencimento à classe operária. Observa-se isso em seu primeiro número, quando o jornal se apresenta no cenário jornalístico:

Não somos eruditos, nem somos herodotos; não freqüentamos Universidades ou Academais para adquirir um papel pelo qual se nos autorizasse a viver sem trabalhar. Os nossos pais não eram burgueses nem mandões, por isso quem pensar encontrar nessas colunas linitivo ao espírito ocioso que produz o riso do burguês

\footnotetext{
${ }^{71}$ Vida Operária, no 6. Manaus, 14 de março de 1920.
}

${ }^{72}$ A Lucta Social, no 1. Manaus, 29 de março de 1914. 
engana-se. A nossa escola é outra: somos operários (...) nós que tudo produzimos e nada possuímos... ${ }^{73}$

Do ponto de vista cultural, embora se possa mencionar uma série de elementos ainda pouco estudados dentro deste universo (produção de peças de teatro, conferências, músicas, poemas e a própria elaboração das festas operárias, dentre outros), destacam-se os elementos culturais que compõem a chamada cultura associativa ${ }^{74}$. Neste caminho, os jornais operários publicaram alguns artigos que expressam todo um universo ritual e simbólico existente no seio daquelas agremiações.

Além de um conjunto de datas festivas (Fundação da Associação; 14 de julho, Queda da Bastilha; 1 o de Maio, Dia do Trabalhador etc.) que eram mencionadas e comemoradas por meio de programações diversas - conferências, apresentações musicais, cortejos, reuniões e outros -, havia toda uma gama de regras e procedimentos realizados nas associações, que eram, em grande medida, publicados nos artigos desses jornais.

Em que pese a realização de comemorações e programações referentes a certas datas e todo o universo ritual e simbólico presente nelas, destaca-se o que se verifica na maioria dos jornais e que parece ser a mais importante das comemorações do universo operário: o 1ㅇ de Maio. A comemoração desta data é tomada aqui não na sua relação com a religião, o Estado, a cidade ou outros setores, mas no que pode esclarecer quanto ao universo da "cultura associativa".

O primeiro ponto a ser destacado é o elemento central presente nos discursos sobre esta data, qual seja: as memórias sobre os acontecimentos de Maio de 1886 em Chicago. Neste ponto se pode identificar tanto a divergência de concepção e particularidades locais da celebração, quanto a disputa travada entre anarquistas e socialistas reformistas pela direção do movimento operário em Manaus. No que concerne a esta última questão, enquanto os anarquistas pretendiam evidenciar a filiação nesta corrente dos "Mártires de

\footnotetext{
${ }^{73}$ A Lucta Social, no 1. Manaus, 29 de março de 1914.

${ }^{74}$ Segundo Cláudio H. M. Batalha, o termo "cultura associativa" possui um duplo significado. Em primeiro lugar, remete ao hábito de associar-se, à tendência de conferir uma certa institucionalidade a formas de sociabilidade diversas. O seu segundo significado é o de cultura das associações. Neste último significado, entende-se por cultura não apenas a produção cultural, no sentido de peças de teatro, conferências, música, mas as celebrações, os costumes, as normas que regiam as associações operárias. É com este último significado que se está empregando o conceito. BATALHA, Cláudio et al. (org.). Culturas de Classe: identidade e diversidade na formação do operariado. São Paulo: Unicamp, 2004, p. 96-100.
} 
Chicago" $^{75}$, os socialistas reformistas buscavam na decisão do Congresso Socialista Internacional, reunido em Paris, a origem desta data ${ }^{76}$.

Embora essas divergências estejam presentes nos discursos sobre o 10 de Maio, a comemoração, em suas diversas faces, frequentemente assumia um caráter ritualístico, conforme se nota em $O$ Extremo Norte, que trouxe uma série de informações acerca das atividades que seriam realizadas nesta data pelas associações existentes em Manaus, como é o caso do Sindicato dos Estivadores.

Pela manhã de hoje, esta novel associação fará em conjunto com as demais sociedades, uma romaria ao Campo Santo, em signal de lembrança aos restos mortaes dos companheiros que jazem eternamente. Às 20 horas haverá sessão magna! E posse dos corpos dirigentes, para a qual não há convite especial ${ }^{77}$.

Era prática da maioria das associações operárias realizar a sessão solene de posse da nova diretoria nesta significativa data. Além disso, no interior dessas agremiações havia toda uma série de atividades voltadas para o Dia do Trabalho.

Em sua sede social à rua Barroso, reuniram se às 17 horas do dia 28, os corpos dirigentes das Artes Graphicas do Amazonas, para deliberarem sobre (...)

De carácter extraordinário, a sessão esteve bastante movimentada e bem concorrida, trocando-se idéias e tomando-se medidas diversas.

Officios, communicações e cartas de outras sociedades desta capital, tudo concernente à magna data de 1 을 de Maio, foi que constou o expediente.

Terminada esta parte, ficou assentada a realização de uma sessão solemne a effectuar-se hoje, às 19 horas, conforme marca os seus estatutos, para a qual são convidadas todas as associações de Manaós.

O sr. Presidente nomeou em seguida várias comissões, que tomarão parte nos festejos de hoje.

75 “A Federação dos trabalhadores dos Estados Unidos e Canadá reunida num congresso em Chicago, em 1881, deliberou votar a greve geral no dia 10 de maio de 1886 para a conquista da jornada de oito horas. Chegado este dia, produziu-se um formidável movimento e a polícia atropela, mata e fere muitos grevistas (...) e em vez de buscar o verdadeiro autor do atentado, prenderam oito libertários..." A Lucta Social, no 2. Manaus, 1으 de maio de 1914.

76 "A idéia da festa do trabalho tem encontrado partidários por toda a parte. A iniciativa de sua creação partiu do Congresso da Federação do Trabalho, reunido em S. Luiz da América do Norte, em 1888, cuja primeira manifestação foi em favor do dia de 8 horas de trabalho. No Congresso Internacional dos operários em Paris de 1889, foi acceita a idéia americana, ficando accordado que o 10 de Maio de 1890, fosse festejado em toda a Europa. A idéia da festa espalhou-se por toda a parte ...". Vida Operária, no 13. Manaus, 10 de maio de 1920.

${ }^{77}$ O Extremo Norte, no 16. Manaus, 1을 de maio de 1920. 
Durante a sessão solemne, terão a palavra oradores já commissionados e, depois, será franca a quem della quizer fazer uso ${ }^{78}$.

As comemorações sobre o 1 을 de Maio se davam tanto no interior das associações como também acabavam por assumir uma dimensão pública. Sobre esse ponto, Michelle Perrot informa que por ser um ato político deliberado dos trabalhadores, esta data frequentemente assumia tal caráter, o que ilustra o lado voluntário da construção de uma classe na tentativa de criar uma identidade universal ${ }^{79}$.

Esta dimensão pública pode ser identificada, de forma contundente, em um artigo publicado pelo jornal A Lucta Social:

\begin{abstract}
Foi assim que o operariado amazonense interpretou e sagrou a 1을 de Maio levando a cabo manifestações diversas quer internas quer externas. Aquelas nas associações de classe, e estas na praça pública, tendo como ponto de partida o largo de São Sebastião, ao qual às 16 horas se juntaram proletários e estudantes dando início ao comício. Adail Couto que pronunciou uma bem improvizada alocução, discorrendo sobre o 1 ㅇ de Maio e terminando, saudou o operariado em nome da classe dos estudantes da Universidade de Manáos. Algumas vivas coroavam as palavras deste acadêmico, o qual foi procedido no uso da palavra pelo artista gráfico J. Azpilicueta... ${ }^{80}$
\end{abstract}

Enfim, ora em local público, ora entre as paredes das agremiações operárias, ou em ambos, palestras, conferências, discursos, cortejos e outras formas de atuação que externam elementos de uma "cultura associativa" operária estiveram presentes na comemoração desta data importante para os trabalhadores de então.

Assim, a produção, manutenção e distribuição dos jornais, sua característica enquanto instrumento de conscientização, mobilização e luta, seu direcionamento à classe operária e suas referências quanto ao universo cultural desta classe são os elementos que singularizam este tipo de imprensa no interior do periodismo amazonense.

Recebido em 15/12/2010

Aceito para publicação em 20/01/2011

\footnotetext{
${ }^{78}$ Idem.

79 PERROT, Michelle. Os Excluídos da História: operários, mulheres e prisioneiros. Rio de Janeiro: Paz e Terra, 1988, p. 127-138.

${ }^{80}$ A Lucta Social, no 3. Manaus, 1ㅇde junho de 1914.
} 